Emotions in Indian

Thought-Systems 
The stereotypical image of the Indian holy man, or the Buddha, detached from the world and unencumbered by emotional states, encourages the impression that Indian spirituality has no place for emotion. While acknowledging the disparagement of emotion in certain schools of thought, the book draws attention to the range of Indian traditions - from philosophy to aesthetics to tantra - that value it profoundly and look upon emotions as offering pragmatic processes for moral, aesthetic and spiritual development. The subtle understandings of emotional life outlined in these essays will be useful not only to those interested in Indian thought as such, but to those concerned with emotional intelligence in cross-cultural thinking.

- Kathleen Higgins, University of Texas

The book presents an excellent array of scholarly essays to be read by South Asian specialists. Indeed, they offer Western (and Indian) researchers and laypersons myriad pointers within dharma traditions that enrich the much-popularised concept of 'enlightenment-as-sheer-presence' with an emotional (rasa) infusion of auspicious longings, conative-affective truths, transformable feeling-states, spiritually matured erotic passion and ranges of personal 'intensity'. Thus, the volume continues the Foucaldian critique of the current scientia sexualis psychologies with their terminal maturity of the 'well-adjusted, desiring-ego', while also presenting glimpses of alternative 'paths of emotional profundity'.

- Stuart Sovatsky, Princeton University 


\title{
Emotions in Indian Thought-Systems
}

\author{
EDITORS
}

Purushottama Bilimoria

Aleksandra Wenta

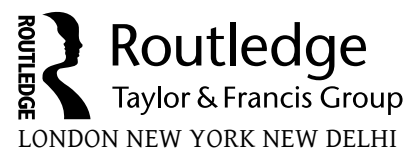




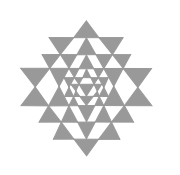

\section{Contents}

Preface

| ix

Emotions in Indian Thought-Systems: An Introduction

$\mid 1$

Purushottama Bilimoria and Aleksandra Wenta

\section{Part I: Tantrism}

1. Passions and Emotions in the Indian

Philosophical-Religious Traditions

Raffaele Torella

2. Intensity of Emotions: A Way to Liberation in the Advaita Śaiva Āgamas and Their Exegetes Bettina Sharada Bäumer

3. Between Fear and Heroism:

The Tantric Path to Liberation

Aleksandra Wenta

\section{Part II: The Bhakti Movement}

4. Principal Emotions Contributing to the Supreme Love of Siva: A Study of Early Śaiva Hymnal Corpus

T. Ganesan

5. Love Never Tasted Quite Like This Before:

Śrngāra-rasa in the Light of Two Texts from

a Sahajiyā Vaișnava Notebook

Neal Delmonico and Aditi Nath Sarkar 


\section{Part III: Buddhism, Pātañjala \\ Yoga and Śaiva Siddhānta}

6. The Buddhist Psychology of Emotions Varun Kumar Tripathi

7. Between Impetus, Fear and Disgust: 'Desire for Emancipation' (Samvega) from Early Buddhism to Pātañjala Yoga and Śaiva Siddhānta Andrea Acri

\section{Part IV: Aesthetics}

8. Moha Kāla: Aporia of Emotion in Indian Reflective Traditions

D. Venkat Rao

Sharad Deshpande

About the Editors

Notes on Contributors

Index 